\title{
Growth Effects of "Heterogeneous" Economic Integration: the Example of EMU Enlargement
}

\author{
Helmut Wagner \\ University of Hagen
}

\begin{abstract}
At present, the European Union (EU) is facing the biggest round of enlargement in its history. Many of the EU accession countries, which are less developed than the incumbents, will seek accession to the European Monetary Union (EMU) soon after the required two-year qualifying period. This is justified by the effort to avoid the danger of financial instability in the period prior to euro-introduction. However, by trying to avoid this danger, some of them may run into another danger, namely of a lack of real convergence. The paper investigates this danger.
\end{abstract}

- JEL Classifications: F02, O49, P2

- Key Words: Economic Integration, Monetary Integration, European Integration, Transition Economies, Convergence

\section{Introduction}

At present, there are many plans and projects for international economic integration all over the world. These not only include integration between similarly developed countries but also integration between differently developed countries. For example, and most prominently, in Europe, the European Union (EU) is facing the biggest round of enlargement in its history. The EU accession countries are countries which differ sharply from the EU core countries in terms

\footnotetext{
*Corresponding address: Helmut Wagner, Professor and Dean of the Department of Economics, University of Hagen, P.O.Box 940, 58084 Hagen, Germany, Tel: +49-2331-9872640, Fax: +49-2331987391, E-mail: Helmut.Wagner@fernuni-hagen.de, Internet: www.fernuni-hagen.de/HWagner (C2002-Center for International Economics, Sejong Institution, All Rights Reserved.
} 
of their economic structures and their per capita incomes ${ }^{1}$; moreover, they also differ among themselves in terms of the development level. Many of these accession countries will seek accession to the European Monetary Union (EMU) soon after the required two-year qualifying period ${ }^{2}$. This is justified by the effort to avoid the danger of financial instability in the period prior to euro-introduction. ${ }^{3}$ However, by trying to avoid this danger, the accession countries, at least the (economically, institutionally and technologically) less developed, may run into another danger or pitfall, namely that of a lack of real convergence (very slow real convergence or even real divergence). The paper investigates this danger or pitfall.

The literature that deals with the question of income divergence usually uses static models (see e.g. Krugman 1981, Krugman and Venables 1995). Only with the use of endogenous growth theory for open economies have models been developed which can result in long-term differing growth rates of single countries (see, for example, Grossman and Helpman 1991, Young 1991, Feenstra 1996, and Aghion and Howitt 1998, Ch. 11). In the endogenous growth theory, the level of

\footnotetext{
They include Bulgaria, Cyprus, the Czech Republic, Estonia, Hungary, Latvia, Lithuania, Malta, Poland, Romania, the Slovak Republic, and Slovenia. All of them will accede to EU in 2004 or 2005, except of Bulgaria and Romania which will follow some years later. Turkey is also an official candidate (one of the early applicants), however, it has been kept waiting by the incumbents and the European Commission for many years for various political and other reasons. The GNP per capita in the candidate countries is, on average, about a third of the EU level, measured in purchasing power standards. It is generally expected that soon after the current round of enlargement there will be new candidateapplicants for EU-accession with even worse starting conditions.

${ }^{2} \mathrm{At}$ the time of EU entry, the new member countries also become members of Economic and Monetary Union (EMU) as phase Three of EMU commenced on January 1, 1999, and an opt-out clause like the one granted to the UK and Denmark will not be available to them. Yet, as they will not be able to adopt the euro at that time, they will become EMU members with a derogation until they fulfill the Maastricht convergence criteria. These criteria are contained in Article 109j of the Treaty establishing the European Community and defined in Protocol 6 of that Treaty (the "Maastricht Treaty") and include the requirement of a two-year qualifying period. It says that the new entrants have to participate in the Exchange Rate Mechanism (ERM-II) of the European Monetary System (EMS) within the normal fluctuation margin without severe tensions for at least two years. See, for example, Wagner (2002a), and Hochreiter and Wagner (2002).

${ }^{3}$ On the danger of financial instability in emerging markets see, for example, Mishkin (2001) and Wagner (2000); related to EMU accession countries see Wagner (2002a). This danger can briefly be described as follows: The complete liberalization of capital markets could increase potential vulnerabilities if capital inflows are poorly intermediated by the domestic financial sector and (or) exceed the absorption capacity of the economy. Presently, the banking sectors in many of the EU candidate countries "do not yet properly fulfil their financial intermediation role", as the European Commission recently reported (EU-Commission 2002a, p. 8). In addition, "the non-bank financial sector in transition countries is still nascent and does not compensate for limited bank intermediation", and "the compliance of the regulatory and supervisory framework for the financial sector and of its implementation with international standards has not yet been fully assessed" (ibid, pp. 8-9; see also ECB 2002, pp. 60-61).
} 
the growth rates and hence the speed of the convergence process depends decisively upon the growth determinants of the endogenous model, such as human capital and knowledge and upon the type of institutions. While many of these growth determinants have been extensively studied with respect to convergence, the question of how strong the effect of giving up fiscal autonomy may be on the convergence has not been sufficiently dealt with yet in the literature. In this paper, by extending the Barro (1990)-model, we develop a simple endogenous growth model that emphasizes this aspect to derive the growth effects of accession to a monetary union by a less developed country.

We start with the assumption that a small country with a lower technological level enters an existing monetary union with a higher technological level, say the EMU. The lower technological level forces it to use more public infrastructure (expenditures) to attain its maximal real growth rate. This requires a higher tax rate in this accession country compared to that in the incumbent countries which have a higher technology level. However, when this (technologically) less developed country enters EMU and thus intensifies trade with the incumbents, ${ }^{4}$ it, being an economically small country, has to adjust its tax rate (at least partially) to that of the (average of the) incumbents. (A general reason for this need to (trend) adjust within an integration area is increased tax competition; see, for example, Wagner 2002b. Further reasons, within the European Economic and Monetary Union, are the requirement to coordinate economic policy, and the political pressure or agreement to harmonize taxes; see, e.g., EU-Commission 2002a.) Therefore, the fiscal autonomy of the accession country is reduced through accession to EMU. This will force it to reduce government expenditure, and hence its real growth rate will decline below its maximum level. This has to (and will) be contrasted with positive trade and technological spillovers from EMU accession. The main conclusion of this paper is that the larger is the development (real convergence) gap between an accession country and the incumbents, the greater is the danger of ending up with low positive or even negative net real growth effects of an accession to EMU.

In section II the main thesis is laid out informally before the model analysis is presented in sections III and VI. Section V concludes.

\footnotetext{
${ }^{4} \mathrm{Cf}$. Rose $(2000,2001)$. In the model, we use the simplifying assumption that entering a currency union implies starting trade with the incumbents.
} 


\section{Trade-off between Real and Nominal Convergence}

A main (economic) motive for a developing or emerging country to enter an economic integration area with more highly developed incumbents is the hope that joining it will stabilize its economy and accelerate its economic development. The same motive is effective in the countries that aspire to join the EMU: they hope that joining the EMU will foster their economic development and lead to a (quicker) convergence of their standards of living to that of the EMU core countries (Wagner 2001). This is in line with the spirit of the European Treaties. These show that an alignment of standards of living at a high level in the participating states was a target of the process of integration from the beginning. For example, the preamble of the European Community Treaty talks of the aim of the contracting states "...to strengthen the unity of their economies and to ensure their harmonious developments by reducing the differences existing between the various regions and the backwardness of the less favoured regions". This idea can also be found in Article 2 of the European Community Treaty, which also expresses the view that monetary union is seen as an instrument for achieving real convergence.

The EMU enlargement has to be compared with this objective. In this paper it is argued that there is a danger or pitfall for some (namely the less developed or advanced) accession countries that the enlargement process may result in a lack of real convergence, i.e. slow(er) instead of quicker real convergence and transitory real divergence, i.e. a (transitory) increase in the backwardness of their standards of living compared to that of the EU core countries.

The argument that premature EMU-enlargement/accession could delay real convergence and, at least for a while, lead to real divergence is based on the fact that accession to the EMU requires the accession countries to run restrictive (austere) fiscal policies which have negative effects on the development of the necessary institutional and infrastructure environment. (Such effects may not only be transitory but can also have a long-term impact, if, for example, public opinion about the desirability of EMU-enlargement in various countries changes and, therefore, the enlargement process is stopped politically in some of these countries.) Such a restrictive fiscal policy will be necessary, particularly in the less-developed accession countries, to meet the Maastricht convergence criteria ${ }^{5}$,

${ }^{5}$ These criteria comprise an inflation criterion, a long-term government bond yield criterion, a government budget deficit criterion, and participation in the Exchange Rate Mechanism (ERM-II). 
and to comply with the rules of the EU Stability and Growth Pact ${ }^{6}$ which have to be complied with indefinitely, i.e. also after accession to the EMU.

The envisaged enlargement will bring economies into the EU that are in a process of catching-up with the EU. ${ }^{7}$ Table 1 shows that the GDP per capita in the candidate countries is, on average, only about a third of the EU level, measured in purchasing power standards, and that there is much heterogeneity among the candidate countries with respect to their GDP per capita levels. (In addition, regional and rural-urban disparities in per capita incomes are considerable within some of the candidate countries, see, e.g., EU-Commission 2002a.) Table 2 illustrates in how far the respective countries have already attained the single Maastricht convergence criteria. One can see that in some countries much still remains to be done to reach these criteria. However, reaching the Maastricht nominal convergence criteria sometime in the near future for a short period of time (to get into the EMU) should not be a real problem for almost any of the accession countries. What is more important is the fact that, also after the EMU entrance, and permanently, the accession countries will be forced to attain the fiscal criteria as well as to comply with the rules of the Stability and Growth Pact. This is independent of the occurrence of (probably many) asymmetric shocks that will hit these countries in the catching-up-period which will be characterized by ongoing structural changes and large uncertainty with respect to economic-social-structural and political changes. In this context, one has also to recognize that wage and price flexibility in the accession countries is still rather limited in general (EBRD 2001) and that the incumbents are not allowed to "bail-out" new member countries which are hit by such shocks and run into a deficit or debt crisis.

According to the official figures listed in the Table 2 of the Appendix, one may think that neither deficit nor the public debt should constitute an obstacle to an early membership to EMU of most of the candidate countries. However, firstly, closer scrutiny reveals that the interest burden of their public debt is

\footnotetext{
${ }^{6}$ The centerpiece of the EU Stability and Growth Pact passed in 1996 is the commitment of the EU countries to avoid excessive budget deficits also after the start of the EMU or accession to the EMU. The incumbents commit themselves to aspire to budget balancing (or surplus) and to accept sanctions if the public deficit exceeds 3 percent of GDP.

${ }^{7}$ The gap that these candidate countries will have to overcome is even greater than it was for the previous entrants into the EU. Not only is the average GNP per head lower, but the institutional underdevelopment and the immaturity of the financial and banking sectors of the Eastern candidates are also greater. For the latter, see, e.g., EU-Commission (2002a) and ECB (2002) and Tables 3 and 4 of the Appendix.
} 
likely to be underestimated in some accession countries and that restructuring and unavoidable fiscal transparency in public sector accounting, which should involve the identification and elimination of loss-(hidden deficit) and public deficitproducing quasi-fiscal activities, may increase their debt significantly (see, e.g., Halpern and Nemeyi 2002). Secondly, there are interdependencies or trade-offrelationships between the various efforts to be taken for reaching all of the Maastricht nominal convergence criteria simultaneously that have to be taken into consideration (see, e.g., Wagner 2002a, and EU-Commission 2002a). As the European Commission states: "There are currently many competing demands on candidate countries public finances, which will still continue in the medium term. On the expenditure side, they must be able to take in the costs of remaining transition-related reforms, the costs associated with the Community acquis including institution building, and the costs of public infrastructure investments". (EU-Commission 2002a, pp. 5-6) ${ }^{8}$.

Insofar, a trade-off may exist between successful catching-up (real convergence) and achieving the budgetary discipline implied by the Maastricht convergence criteria and the rules of the Stability and Growth Pact. Therefore, some of the accession countries may run into a problem when they try to reach real and nominal convergence at the same time. ${ }^{9}$ The main reason for a trade-off between real and nominal convergence lies in the following: catching-up can be sustained only if there is an adequate public infrastructure. Provision of this infrastructure may require high rates of public investment. As the rate of return on this public investment would be high, deficit financing may be justified in the accession countries. In these circumstances, a budget deficit above $3 \%{ }^{10}$ and certainly above the "close to balance" rule of the Stability and Growth Pact (SGP) may be optimal for these countries. Even a rate of inflation above the required convergence level may seem desirable to these countries as they can profit from

\footnotetext{
${ }^{8 *}$ From a medium- and long-term perspective, in many countries, still outstanding structural reforms in the health, pension, and social protection area will play a key role in ensuring medium- and long-term sustainability of public finances". (EU-Commission 2002a, p. 6)

${ }^{9}$ This means that ERM-II participation and the adoption of the euro may need to be postponed for some time after EU accession in some of the EMU candidate countries. This is the case if it is believed that in all candidate countries the reform agenda relating to accession and real convergence must have priority over policy moves inspired by full EMU participation (Stage III).

${ }^{10}$ The fiscal convergence criteria of the Maastricht Treaty restrict the government budget deficit and the government debt to certain (politically accepted) levels. A country which wants to participate in the EMU may not have (i) a government budget deficit higher than $3 \%$ of GDP, and (ii) a government debt ratio of more than $60 \%$ of GDP or be approaching that level sufficiently fast.
} 
seigniorage revenues (as long as they keep their own currency). ${ }^{11}$ Hence, it can be argued that the Maastricht fiscal convergence criteria for accession to EMU and the SGP rules are too rigid for the Eastern European candidate countries, at least for those with still imperfect or weak institutional and infrastructure environments.

Nevertheless, the fact remains that all accession countries have to satisfy these convergence criteria and comply with the rules of the Stability and Growth Pact, and that they also have to do this after admission to the EMU. That is, to accede to and to stay in the EMU, they have to reduce their inflation rates and their deficit ratios and keep them (at least for a while) at an individually-suboptimally-low level. Hence, they will be restrained with respect to fiscal financing of budget deficits. Moreover, by acceding to EMU, they lose their control over monetary policy so that they cannot monetarily finance their budget deficits autonomously any more. This means, to finance a given amount of government expenditures, some accession countries would have to raise their tax rates. As empirical evidence shows, often this is not politically feasible. Hence, there may be no other choice for them but to reduce government expenditure to satisfy the Maastricht convergence criteria and to comply with the rules of the Stability and Growth Pact. Reducing only the consumption or welfare state parts of government expenditure will be politically difficult (in particular, accession countries where the welfare state is much less developed than in the rest of the $\mathrm{E}(\mathrm{M}) \mathrm{U}$ may feel they have the "right" to catch up with the rest of the community).

Furthermore, there is currently a clear tendency (consensus) or will in the EMU core countries to reduce their government sector share in GNP over the next decade, i.e. to decrease their general government revenue share and their general government expenditure share, partly in reaction to the external competition pressure induced by the globalization process (Wagner 2002b). It is expected that the new entrants into the EMU will then be forced to reduce or adjust their tax (revenue) share in GNP as well, in order to adjust to the tax harmonization efforts within the EU and to avoid a loss in their external competitiveness (see above; see also Table 5 for the present values of the

\footnotetext{
${ }^{11}$ It may be feared that accession countries will respond with what is sometimes called the "weighing-in" syndrome: they may maintain very tight macroeconomic policies and resort to various techniques to squeeze down inflation prior to accession, only to revise the course and ignore the criteria after they enter EMU. This would, however, result in economic and political problems and quarrels within the enlarged EMU. Moreover, the looser the commitment to pursue macroeconomic policies that will ensure internal and external stability, the less likely it is that a rigidly fixed system can survive the pressures of the market.
} 
expenditure and revenue shares ${ }^{12}$ ). Simultaneously, however, they would need to expand their general government expenditure share in GNP (at least for a while) to finance institutional and public infrastructure investments which are necessary for real convergence and external competitiveness as well as for attracting more foreign direct investment. However, as argued, other revenues, such as seigniorage revenues, will also decline and budget deficits will have to be permanently decreased, according to the Maastricht Treaty and the Stability and Growth Pact. Therefore, the necessary higher government expenditures could then (if not through a higher tax base) only be replaced by a higher inflow of foreign direct investment or by higher subsidies. However, the inflow of foreign direct investment is endogenous, i.e. dependent upon the infrastructure (as argued above), and none of the accession countries can, not even approximately, expect such big transfer payments as East Germany, which was in a similar position a decade ago after the unification with West Germany, has received from West Germany over the past decade.

Therefore, the public investment in infrastructure will likely have to be decreased in some of the accession countries to meet declining government revenues and comply with the rules of the SGP. This will decrease the real growth rate in these countries. ${ }^{13}$

The main problem is that the Maastricht Treaty only requires, as a precondition for EMU-entrance, that the candidate countries fulfil the Maastricht nominal

\footnotetext{
${ }^{12}$ One can see from Table 5 that the present values of the expenditure and revenue shares, at least in the advanced candidate countries, are similar to those in the economically largest EU incumbent, Germany, and far higher than those in the USA (see also EU-Commission 2002b).

${ }^{13}$ See also the European Commission's "Report on Macroeconomic and Financial Sector Stability Developments in Candidate Countries" (EU-Commission 2002a). Moreover, in the run-up to EMU, quick disinflation (within the one-digit-area) in the accession countries to satisfy the Maastricht inflation convergence criterion for entrance into EMU appears (because of nominal rigidities) to be impossible without restrictive fiscal policy, i.e. lower rates of public investment.

Even successful real catching-up (based, e.g., on higher productivity) then involves problems in that it adds to upward pressure on the real exchange rate and hence produces inflationary pressure and thus aggravates nominal convergence (Balassa-Samuelson-effect). The Maastricht inflation criterion can then only be achieved either through an appreciation of the nominal exchange rate, or (if this is not desired or possible because of the limited range of permitted fluctuations within the EMR-II system which the accession countries have to enter before adoption of the euro), through more restrictive monetary and fiscal policies, which would jeopardise public investment, growth and employment. Moreover, if such a productivity gap continues to exist after EMU-enlargement, not only the accession countries but also the EU core countries may be hurt. As the average inflation rate in the core countries then has to decline (to compensate for the higher inflation rates in the new member countries, in order to meet the common inflation target), also the EU incumbents may be forced to run a more restrictive fiscal policy than otherwise. See Wagner (2002a).
} 
convergence criteria at a certain point of time. However, the state of real convergence or, resp., the institutional basis for sustained development and steady fulfilment of the Maastricht and SGP criteria, without being able to use exchange rate adjustment as a national policy instrument, will not be examined as an entrance criterion ${ }^{14}$. Tables 3 and 4 illustrate that the development gap between some of the candidate countries and the average of the incumbents is still significant in many areas (see also footnote 3 above). This has also been demonstrated in various recent studies (e.g. EBRD 2000, 2001, IMF 2000, Deutsche Bank Research 2001, 2002, EU-Commission 2002a). ${ }^{15}$ Furthermore, implementation and enforcement of the legal rules compliant with the acquis communautaire and international standards is often still deficient (cf. EUCommission 2002a). ${ }^{16}$

The typical (counter-)argument against the above argumentation is twofold: on the one hand, it is asserted that EU accession is already acting as a catalyst for quick progress on the structural front and for the reinforcement of macroeconomic stabilisation. The reason is that in order to be allowed to enter the EU, the candidate countries have to prove that they have adopted the legal and institutional acquis communautaire and that they fulfil the "Copenhagen criteria", which are supposed to indicate the ability of a country to withstand competitive pressure and market forces without protective regulations. However, it is difficult to assess exactly what constitutes fulfilment of the Copenhagen criteria which leaves a lot of room for discretionary political decisions and compromises. The problem is (as mentioned earlier) that, as entrance criteria into the EU, the Copenhagen criteria

\footnotetext{
${ }^{14}$ The EU-council (consisting of the heads of governments of the EU member countries), which will have to decide on EMU-accession, will certainly discuss such aspects against the background of the Copenhagen criteria, however it is hardly imaginable that it will reject an official candidate country that fulfills the Maastricht nominal convergence criteria. One reason for this is political, the other one is that the Copenhagen criteria are "soft" criteria, i.e. they are not measurable to the same extent as the Maastricht nominal convergence criteria, and therefore leave broad room for discretionary political decisions. (Even partial non-satisfaction of the Maastricht criteria need not be a hindrance to EMUadmission as long as a candidate country promises to approach the critical levels sufficiently fast, as the example of Greece has recently shown.)

${ }^{15}$ See also Table 4 which shows the transition indicators of the European Bank for Reconstruction and Development.

${ }^{16}$ Here, the European Commission mentions as particularly relevant areas: "transposition and implementation of international accounting standards; auditing and disclosure rules; prudential rules; supervision, including consolidated supervision and national and cross-border co-operation between supervisory authorities; autonomy, resources and enforcement powers of supervisory authorities; a financial safety net, including a deposit insurance system which discourages moral hazard; and appropriate crisis management arrangements". (EU-Commission 2002a, p. 11)
} 
are "soft" criteria whereas the Maastricht nominal convergence criteria are "hard" criteria (because they are measurable) what is more. Moreover, it is highly questionable whether the accession countries will already have had to have adopted the whole acquis communautaire at the point of time of accession. The adoption of some (among them some crucial) elements will likely be left for the after-accession period. Furthermore, adoption and implementation or enforcement are different topics. Only enforcement of the respective rules will ensure sustainable development and the ability to withstand competitive pressure and market forces in a global economy without protective regulations. ${ }^{17}$

On the other hand, a second counter-argument asserts that there will be an endogenous process of institutional adjustment and real convergence that works particularly through (i) a greater inflow of FDI and (ii) greater labour market flexibility and is induced by (the expectation of) EMU-accession.

On (i): there is no doubt that in the short term many candidate countries will still be able to rely, to a considerable extent, on privatisation-related FDI inflows, as a means to finance their current account deficits. However, as the privatisation process is nearing completion, current account deficit financing will have to increasingly rely on more short-term and easier-to-reverse capital inflows. Here, the rules of the SGP will be binding. Moreover, as argued above, a higher inflow of FDI is endogenous, i.e. dependent upon better infrastructure (which has still to be developed, see above).

On (ii): with respect to the argument of EMU entrance inducing higher labour market flexibility, the experience of East Germany after the East-West-German unification should be examined. This example has shown that not all of the relevant institutional preconditions for catching-up (including the traditional OCA-criteria) automatically or endogenously progress, but that some even may get worse, such as flexibility conditions on labour markets (for more details see, e.g., Wagner 2002a, Wagner 1993, Sinn 2002).

\section{The Model}

The basic idea of the danger of ending up in slower real convergence or even divergence for a small accession country can be presented using a simple model.

We use a 2-country growth model with public goods and assume that a small

\footnotetext{
${ }^{17}$ In this context see also footnote 3 above, in the light of the generally accepted accession of 10 candidate countries to the EU in 2004 or 2005.
} 
country (country B) intends to accede to an existing (big) currency union (country A). Initially, both countries are assumed to be totally autarkic, i.e., there are no economic links. Countries A and B are assumed to be largely identical (except for their sizes). There are only two differences (besides of size): first, country A is technically more advanced than country B; second, the output effect of public investment in country B is larger than in country A (that is, we assume a higher output elasticity of public investment in country B than in country A). In the following model, the growth rate of country B can be affected by variations in public expenditure. Therefore, the accession to the currency union (country A) can lead to negative growth effects for country B. The reason is that the fiscal autonomy of country $B$ is reduced through the accession to the currency union. We shall assume that the accession to the currency union will require a decline in the public (government) sector share in the gross national product. This will reduce public investment and thus the growth rate of country B.

At first, we develop a model of a closed economy (country A). The model is an extension of the Barro (1990)-model. The model economy has two sectors: capital and consumer goods, and two production factors: labour and capital. In the capital goods sector, productivity can be increased by public investment (e.g., by establishing a stable legal framework and implementing institutional infrastructure). This resembles the view substantiated by numerous studies of the endogenous growth theory that there is a positive correlation between the institutional environment and the economic growth of a country or economy. Growth can be fostered by investing in institutions and infrastructure, and we assume this cannot be done without increasing public investment or services (see also Barro and Sala-I-Martin 1992). ${ }^{18}$

The firms in our model consider the quantity of public services to be exogenous. To exclude scale effects, we assume that the state provides public services with congestion. ${ }^{19}$ Public expenditure is financed by tax incomes. The

\footnotetext{
${ }^{18}$ One can, however, argue that some so-called public goods could be provided by private producers more efficiently. Particularly in developing and transition or emerging economies, however, the institutional weakness (lack of legal and other, economic-social-political, infrastructure) requires that governments be involved in the production of those goods. This resembles the experiences of developing and emerging countries, that privatisation is only efficient if the essential infrastructure or institutions are already in place (on the pitfalls of privatization without prior institutional precautions see, e.g., Stiglitz 2002).

${ }^{19}$ This means that we model a congestion effect: Many state activities such as water systems, highways, police and fire services, and courts are subject to congestion. For a given quantity of aggregate state services, G, the quantity available to an individual declines as other users congest the facilities.
} 
production function of a producer, $j$, in the capital goods sector of country $A$ is:

$$
Y_{j}=B^{A} K_{j}[G /(1-h) K]^{1-\beta^{A}}
$$

where $Y$ is output, $B$ is a productivity parameter which reflects the technological level, $K_{j}$ is private capital input by producer $j, G$ is government expenditure, (1$h)$ is that part of the current capital stock $(\mathrm{K})$ which is used in the capital goods sector, and $0<1-\beta<1$ denotes the output elasticity of the public goods with congestion. The superscript $A$ is inserted only when there is a deviation from the values of country $B$ (see below). For given $G$ and $K$, the firm's production exhibits constant returns with respect to the private input $K_{j}$. The production process equals the AK model modified by the term that involves public services. An increase in $G$ relative to $(1-h) K$ expands $Y_{j}$ for given $K_{j}$. Because of congestion, only an increase in $G$, relative to the capital input in the capital goods sector, $(1-h) K$, increases the marginal productivity of the private capital. An increase of $(1-h) K$ for given $G$ lowers the public services available to each producer and therefore reduces $Y_{\mathrm{j}}$. As long as $G /(1-h) K$ is constant, the marginal productivity of $K_{j}$ is also constant, and steady endogenous growth results.

We suppose that the government runs a balanced budget financed by a proportional tax at rate $\tau$ on $Y$ :

$$
G=\tau Y
$$

The firms in the capital goods sector thus have to pay a part of their gross income to the government.

The producers in the consumer goods sector use the remaining capital stock $(h K)$ and labour to produce consumer goods. We assume the following production function for firm $i$ :

$$
X_{i}=\left(K L_{i}\right)^{1-\alpha} K_{i}^{\alpha}
$$

where $0<\alpha<1 . X$ denotes output of consumer goods and $L$ describes the (constant) labour force. The production function implies that the stock of knowledge is linked to the stock of capital. The stock of knowledge is available to all producers, i.e. knowledge is a public good. The function is linearly homogenous in the private factor inputs. On the level of sectors, however, there are 
increasing returns to scale.

By aggregating (1) and inserting into (2), one gets:

$$
G=(1-h) K\left(\tau B^{A}\right)^{\frac{1}{\beta^{A}}}
$$

The higher the tax rate and the higher the level of technology, the higher is the government expenditure. By inserting (4) into the first order condition for profit maximisation in the capital goods sector ${ }^{20}$, one gets the equilibrium rate of interest conditional upon the tax rate:

$$
r+\delta=(1-\tau) \tau^{\frac{1-\beta^{4}}{\beta^{4}}}\left(B^{A}\right)^{\frac{1}{\beta^{4}}}
$$

where $r$ denotes the rate of interest, and $\delta$ describes the rate of depreciation.

The interest rate is positively dependent upon the level of technology. There are no transitory dynamics and all variables exhibit the common growth rate $\gamma$.

Now we introduce the behaviour of households. The representative (infinitelived) household maximises overall utility. Assuming the common functional form for the utility function, utility is given by

$$
U=\int_{0}^{\infty} \frac{c^{1-\theta}-1}{1-\theta} e^{-\rho t} d t
$$

From this we get, after some algebra, the equilibrium rate of growth conditional upon the tax rate:

$$
\gamma=\frac{1}{\theta}\left[(1-\tau) \tau^{\frac{1-\beta^{4}}{\beta^{4}}}\left(B^{A}\right)^{\frac{1}{\beta^{4}}}-\delta-\rho\right]
$$

\footnotetext{
${ }^{20}$ After aggregating the firms on the sector level, from profit maximization of the firms (under imperfect competition), we get the following first order conditions:

(x) $\alpha h^{\alpha-1} L^{1-\alpha} \stackrel{!}{=} p(r+\delta)$

(xx) $(1-a) L^{-a} h^{a} K \stackrel{!}{=} w$

$(\operatorname{xxx})(1-\tau) B^{A}[G /(1-h) K]^{1-\beta^{A}} \stackrel{!}{=} r+\delta$

where $r$ is the rate of interest, $\delta$ denotes the rate of depreciation, and $w$ is the wage level; $p$ denotes the price of the capital good in units of the capital good.
} 
The effect of government on growth involves two channels. On the one hand, an increase in the tax rate lowers marginal productivity of capital after taxes and therefore reduces the rate of growth; on the other hand, an increase in the tax rate raises the provision of public goods and hence increases the growth rate.

Now we assume that the government selects a tax rate that maximises the growth rate. By setting the derivative of (7) to zero, we get

$$
\tau^{A}=1-\beta^{A}
$$

By inserting (8) into (7), the maximal growth rate in country $A$ is given by

$$
\gamma^{A}=\frac{1}{\theta}\left[\beta^{A}\left(1-\beta^{A}\right) \tau^{\frac{1-\beta^{A}}{\beta^{A}}}\left(B^{A}\right)^{\frac{1}{\beta^{A}}}-\delta-\rho\right]
$$

Now we come to model country $B$ (the accession country). We assume that country $A$ exhibits a higher level of technology. That is, we assume that the productivity of private capital in country $A$ is higher than in country $B: B^{B}<B^{A}$. Furthermore, we assume that the output elasticity of public goods with congestion in country $B$ is higher than in country $A$ : $\beta^{B}<\beta^{A}$. This implies that country $B$ profits from public investments to a greater extent than country $A \cdot{ }^{21}$ Otherwise, countries $A$ and $B$ are symmetric (except of size).

Hence, the aggregated production function in the capital goods sector of country $B$ is given by:

$$
Y=B^{B}(1-h) K[G /(1-h) K]^{1-\beta^{B}}
$$

Also in country $B$, the government runs a balanced budget financed by a proportional tax at rate $\tau$ on $Y$ :

$$
G=\tau Y
$$

By doing the same calculation steps as above, we get the growth rate of country $B$ conditional upon the tax rate as

\footnotetext{
${ }^{21}$ The reason is that the provision of a functioning (developed) infrastructure (which still has to be developed or implemented in a transition country such as B) induces a higher growth push than an improvement in an already available, functioning infrastructure (as in country A) does.
} 


$$
\gamma=\frac{1}{\theta}\left[(1-\tau) \tau^{\frac{1-\beta^{B}}{\beta^{B}}}\left(B^{B}\right)^{\frac{1}{\beta^{B}}}-\delta-\rho\right]
$$

The growth-rate maximising tax-rate is

$$
\tau^{B}=1-\beta^{B}
$$

where $\tau^{B}>\tau^{A}$.

It is obvious that the growth-maximising tax rate in country $B$ is higher than in country $A$. The reason is the higher output elasticity of government expenditures, as described above. The government in country $B$ therefore takes a more active role in the growth process than the government in country $A$. Hence, the government sector share in the GNP in country $B$ is higher than that in country $A$. This corresponds to an often-formulated policy advice for developing and transition countries that are faced with a specific shortage of public goods (Zhang 2000). ${ }^{22}$

The different tax rates lead to differing growth rates and thus to divergence. Now the question is whether the growth rate in country $B$ is higher than that in country A. This can be examined by inserting (13) into (12). We then get the maximal growth rate in country $B$ as

$$
\gamma^{B}=\frac{1}{\theta}\left[\beta^{B}\left(1-\beta^{B}\right)^{\frac{1-\beta^{B}}{\beta^{B}}}\left(B^{B}\right)^{\frac{1}{\beta^{B}}}-\delta-\rho\right]
$$

We have supposed three differences between countries $A$ and $B$ : their sizes, the level of technology, and the level of output elasticity of public goods with congestion. The technological advantage of country $A$ over country $B$ leads to a higher growth rate in country $A$. However, the direction of the output elasticity effect is ambiguous. Therefore, we cannot say unambiguously, whether the growth rate in autarky of country $A$ is higher or lower than that of country $B$.

\section{Growth Effects of Accession}

Now we can analyse which growth effects are induced by the accession of a

\footnotetext{
${ }^{22}$ And it corresponds to the above-mentioned view supported by the endogenous growth theory, that growth positively correlates with investment in adequate infrastructure or institutions, which still have to be developed in transition or emerging market economies (to fill the institutional gap and catch up with the standard of living in the advanced industrial countries) and, to a large extent, are public goods.
} 
small country (country $B$ ) to the union (country $A$ ). The assumption of a small country implies that the enlargement of the union has no influence on the endogenous variables of country $A$. The growth rate of country $A$ will not change. As explained above, we assume that accession to the union requires that country $B$ lowers its government expenditure. In the above model structure, this is synonymous with a reduction of the tax rate. For simplicity (and without any consequences for our basic results), we assume that all countries of the union have to implement a common tax rate. That is, we assume that country $B$ has to implement the lower tax rate of country $A\left(\tau=1-\beta^{A}\right)$. The accession country thus cannot implement a fiscal policy according to its national preferences any more. It has to reduce public investments (below the level desired in autarky) so that it is confronted with a decrease of its growth rate. ${ }^{23}$

So far, we have only concentrated on potential negative effects of an accession to the union for the accession country. However, there are also potential positive growth effects for the accession country. We can assume that the accession country $B$ profits from the higher level of technology in the union (country $A$ ) after admission to the union. The resulting spillovers are positively dependent upon the difference in technology. That is, the higher the technology gap, the higher are the spillovers. ${ }^{24}$ Furthermore, the spillovers are also determined by the extent of economic integration (proxied by trade flows) ${ }^{25}$ as well as by further factors of influence (in particular, transfer payments and other integration programs, these factors could be modelled by variations of $\lambda$, see below). Depending on the strength of the positive and negative growth effects explained above, accession to the union leads to either an increase or a decrease of the growth rate of the accession country.

We model this by supposing the following production function in the capital goods sector of country $B$ :

\footnotetext{
${ }^{23}$ If we change the assumption that $\mathrm{B}$ is a small country into $B$ being a big country (interpreted as the group of admitted accession countries), then it may appear useful to assume that the common tax rate in the union is a mean of the tax rates in autarky. In this case, it is possible (in the above model) that country A has to suffer from loss in growth as a consequence of the entrance of country $B$. (Because of the technology leadership, spillovers are lower for country A than for country $B$.) Then it is possible that both countries have to suffer from a decline in their growth rates. However, this does not necessarily imply a loss in welfare. To prove this, the solution of the model would have to be calculated, and a welfare analysis would have to be carried out.

${ }^{24}$ This seems to be an adequate assumption as long as the technology gap is not too big. See, e.g., Xie (1999).

${ }^{25}$ See e.g., Bayoumi et al. (1999), Merikas et al. (2000), and Long and Wong (1997).
} 


$$
Y=\left[B^{B}+\lambda f\left(\frac{T}{Y}\left(B^{A}-B^{B}\right)\right)\right](1-h) K[G /(1-h) K]^{1-\beta^{B}}
$$

where $\frac{\partial f}{\partial(T / Y)}>0$, and $\frac{\partial f}{\partial\left(B^{A}-B^{B}\right)}>0$.

In order to exclude that the spillovers increase the level of technology in country $B$ beyond the level in country $A$, we moreover assume that $\lambda f \leq B^{A}-B^{B}$ where $\lambda$ denotes the strength of the spillovers, and $0 \leq \lambda \leq 1 . T$ denotes trade flows, and $B^{A}-B^{B}$ delineates the technology gap between countries $\mathrm{A}$ and $\mathrm{B}$. It is obvious that for $\lambda=0$, the production function remains unchanged, and there are no spillovers.

By considering the reduced tax rate and the changed production function, we can derive the growth rate in the (small) accession country after admission to the union:

$$
\gamma^{B}=\frac{1}{\theta}\left[\beta^{A}\left(1-\beta^{A}\right)^{\frac{1-\beta^{B}}{\beta^{B}}}\left[B^{B}+\lambda f\left(\frac{T}{Y}\left(B^{A}-B^{B}\right)\right)\right]^{\frac{1}{\beta^{B}}}-\delta-\rho\right],
$$

We see that the growth effect of an accession to the union is not unambiguous: While the exogenously given tax rate $\tau=1-\beta^{A}$ tends to lower the growth rate, the spillovers increase the growth rate. It depends upon the strength of the individual effects whether the growth rate increases or decreases. Only for $\lambda=0$ we can unambiguously state that there will be a decline in the growth rate in country $B .^{26}$

However, it makes sense to assume that directly after enlargement of the union, $\lambda$ tends to be low. This means that the accession to the union tends to result in a decrease of the growth rate in country $B$, at least initially. ${ }^{27}$ In order to be consistent in our argument we have to interpret $\lambda$ as the strength of the spillovers of integration. The spillovers of integration, however, usually become significantly effective only after the accession of the new member countries. ${ }^{28}$ Hence it makes sense to assume that $\lambda$ will only gradually increase so that it is very likely that

\footnotetext{
${ }^{26}$ We cannot generally determine whether the growth rate in country B will be higher or lower than in country A. If, however, the growth rate in country B is higher, the assumption that B is a small country would have to be revised in the long run. In general we can state that the higher the trade ratio and the higher $\lambda$, the more likely it is that the growth rate in country B will lie above that in country A.

${ }^{27}$ Note, however, that the above model does not include transition dynamics.

${ }^{28}$ Actually, there may already be positive spillovers before EMU entry because accession countries may attract capital inflows as investors anticipate the convergence of interest rates and the appreciation of their exchange rates. Nonetheless, spillovers will gradually increase after EMU entry.
} 
the positive growth effects of an accession to the union will be low in the beginning (in particular for accession countries with a large development gap) ${ }^{29}$. Therefore, the negative growth effects worked out above will tend to outweigh the positive effects during the first period of time after union accession (in those countries). That is, before and after the admission to the union, the growth rate in country $B$ may decline for a while. If this leads to political disappointment, it may result in turmoil and pressure for redistribution within the union that would destabilise and (at worst) eventually stop further integration processes (especially in the case when several such countries are admitted and run into such problems simultaneously). ${ }^{30}$

\section{Conclusions}

The paper examines the growth effect of heterogeneous economic integration using the example of the present EMU enlargement process. It argues that the fiscal autonomy of an accession country is reduced through the accession to the EMU (the big union). In the model used, this will force the accession country to reduce its government expenditure (instead of increasing it, which would be necessary for financing the development of its institutional and infrastructure base in order to reach the goal of quick real convergence, i.e. to catch up quickly with the standard of living in the richer EMU core countries) $)^{31}$, and hence its real growth rate will decline below its maximum level. ${ }^{32}$ This is contrasted with positive trade and technological spillovers from entering a big union such as the EMU that consists of (technologically) more highly developed incumbents. The main conclusion drawn in this paper is that, the larger the development (real

\footnotetext{
${ }^{29}$ In the model, we assumed that the higher the technology gap, the higher are the spillovers. However, in practice, we have to consider a factor which is usually associated with such a technology gap - that the higher the technology gap, the greater is the lack of institutions. A significant lack or low standard of institutions (schooling etc.), however, presents a hindrance to exploiting the technology input so that the positive growth effects in country B may not eventuate to a great extent.

${ }^{30}$ This may even occur earlier if the financial markets' anticipation of a particularly costly ("big-bang") EMU-enlargement strategy triggers an anticipatory EU-wide recession, which is analysed in Wagner (2002a, 1996).

${ }^{31} \mathrm{An}$ additional aspect that further strengthens the argument that less-advanced candidate countries may weaken their catch-up process by entering EMU too early is that it leads to an ongoing loss of external competitiveness in the emerging economies after EMU accession (see Bundesbank 2001).

${ }^{32}$ The model used here is a long-term endogenous growth model. Therefore, taxes and government expenditures have to move in the same direction (government's long-term intertemporal budget constraint). In a short-to-medium-term model, however, we could derive a decrease in government expenditure and a simultaneous increase in the tax rate as a consequence of, or compensation for, the loss of monetary and debt financing of budget deficits. Both measures would decrease output and therefore tend to lead to real divergence.
} 
convergence) gap between an accession country and the incumbents, the greater is the danger of ending up with low positive or even negative net real growth effects of an accession, at least for some period of time. In general, however, dependent upon the strength of the two opposite effects, the growth rate of the accession country may decrease or increase. As the growth rate of the union is not affected by the accession of a small accession country, different situations can eventuate. An initial convergent/divergent development can be accelerated or slowed down. Or an initial convergent/divergent development can be reversed by the accession. For example, the accession country may initially have a higher growth rate than the union; however, caused by the restrictive government expenditure policy associated with a decrease in the tax rate enforced by the accession, the growth rate of the accession country may be lower after accession.

The general political implication of this study is that premature accession (with imperfect or weak institutions) of less developed emerging countries to an economic and/or monetary union that consists mainly of more highly developed industrial countries may be costly for the accession countries and, moreover (however not examined in this paper), also for the incumbents. If the candidate countries with weak (imperfect) institutions decide to enter such a monetary union, they must accept the risk that they may not achieve (stronger) positive growth effects and may have a lower ability to adjust to shocks and cope with secular changes. ${ }^{33}$ Anyway, they achieve lower growth effects than they would have had they entered with stronger institutions. This cost or risk of lower growth in the case of early accession has to be balanced by (concerns about) the cost or risk of waiting that, in the case of EMU-enlargement, mainly consists of the risk of financial instability (speculation) during the ERM-II-qualification period ${ }^{34}$ and the loss or weakening of a key anchor for the domestic policy agenda in the candidate countries ${ }^{35}$. Nevertheless, with regard to the EMU accession countries, it may be better for some of them (namely

\footnotetext{
${ }^{33}$ Another critical point or cost associated with premature accession is the following: The accession of less developed emerging economies to an economic and/or monetary union that consists mainly of more highly developed industrial countries increases the asymmetries in the macroeconomic structures of the union. These asymmetries create new challenges or strains for the common central bank as the common monetary policy then creates, to a greater extent, different adjustment reactions in the individual member countries. Different business cycles and tensions within the union are then predetermined.

${ }^{34}$ See Wagner (2002a).

${ }^{35}$ The IMF, for example, emphasizes that accession aspirations should "help these countries maintain the momentum of progress that is needed with fiscal reforms, privatization, other structural improvements, and environmental cleanups". (IMF 2002, p. 39)
} 
the economically, technologically, and institutionally less developed) to wait and maintain flexible exchange rates after EU-accession for a while and use the time to improve institutional fundamentals. ${ }^{36}$ Importantly, however, this choice should be left to the candidate countries to avoid the momentum of reform progress in these countries being significantly slowed down.

\section{Acknowledgement}

I thank Florian Spaete for research assistance and Gerhard Illing, Jens Hoelscher, Eduard Hochreiter, Friedrich Kissmer, Wolfram Berger, Gyorgy Szapary, and Thomas Willett for discussions or comments on a previous, much longer version that was presented at an international conference of the Deutsche Bundesbank in Frankfurt in November 2001 and at the 77th Annual Conference of the Western Economic Association International in Seattle in June 2002.

Received 25 January 2002, Accepted 9 July 2002

\section{References}

Aghion, P., Howitt, P. (1998), Endogenous Growth Theory, Cambridge, Mass., MIT Press. Barro, R.J. (1990), Government Spending in a Simple Model of Economic Growth, Journal of Political Economy, 98, 103-25.

Bayoumi, T., Coe, D.T., Helpman, E. (1999), R\&D Spillover and Global Growth, Journal of International Economics, 47, 399-428.

Bundesbank (2001), Monetary Aspects of the Enlargement of the EU, Deutsche

Bundesbank Monthly Report October 2001, 53, 15-30.

Deutsche Bank Research (2002), EU Enlargement Monitor. Central and Eastern Europe, No. 7 (17 April 2002), Frankfurt a. M., Deutsche Bank Research.

EBRD (2000), Transition Report 2000, London, European Bank for Reconstruction and Development.

EBRD (2001), Transition Report 2001, London, European Bank for Reconstruction and Development.

ECB (2002), European Central Bank Monthly Bulletin July 2002, 51-63.

EU-Commission (2002a), Report on Macroeconomic and Financial Sector Stability Developments in Candidate Countries, by Directorate-General for Economic and Financial Affairs of the European Commission, European Economy Number 8, April

\footnotetext{
${ }^{36} \mathrm{Or}$, as the European Commission recently pointed out: "the priority should remain on improving the functioning of the budgeting process, carrying out structural reforms, implementing the acquis communautaire, and supporting catching up". (EU-Commission 2002b, p. 126)
} 
Growth Effects of Heterogeneous Economic Integration: the Example of EMU Enlargement 643

2002 (Issn 1608-9022), ECFIN/143/02-EN-Final.

EU-Commission (2002b), Public Finances in EMU 2002. Part V : Key budgetary issues for the candidate countries of Central and Eastern Europe, by Directorate-General for Economic and Financial Affairs of the European Commission, European Economy Number 3/2002, Brussels, 111-129.

Feenstra, R.C. (1996), Trade and Uneven Growth, Journal of Development Economics, 49, 229-256.

Grossman, G.M., Helpman, E. (1991), Innovation and Growth in the Global Economy, Cambridge, Mass., MIT Press.

Halpern, L., Nemeyi, J. (2002), Fiscal Foundation of Convergence to European Union in Pre-Accession Transition Countries, Discussion Paper 03/02 (January 2002), Economic Research Centre of the Deutsche Bundesbank, Frankfurt/M..

Hochreiter, E., Wagner, H. (2002), The Road to the Euro: Exchange Rate Arrangements in European Transition Economies, Annals of the American Academy of Political and Social Science, 579, 168-182.

IMF (2000), Finance and Development, Economies in Transition, September, Washington, DC, International Monetary Fund.

IMF (2002), World Economic Outlook April 2002 Recessions and Recoveries, Washington, DC, International Monetary Fund.

Krugman, P. (1981), Trade, Accumulation and Uneven Development, Journal of Development Economics, 8, 149-61.

Krugman, P., Venables, A. (1995), Globalization and the Inequality of Nations, Quarterly Journal of Economics, 110, 857-80.

Long, N.V., Wong, K. (1997), Endogenous Growth and International Trade: A Survey, in Dynamics, Economic Growth, and International Trade (Ed.) Jensen, B.S., Wong, K., Ann Arbor, 11-74.

Merikas, A., Vozikis, G.S., Merikas, A. (2000), Trade Openness and Economic Growth Revisited, Journal of Applied Business Research, 16, 75-85.

Mishkin, F. S. (2001), Financial Policies and the Prevention of Financial Crises in Emerging Market Countries, NBER Working Paper 8087.

Rose, A.K. (2000), Currency Unions and Trade: The Effect Is Large, Economic Policy, 30, 7-45.

Rose, A.K. (2001), One Money, One Market: The Effect of Common Currencies on Trade, Economic Policy, 33, 449-461.

Sinn, H.-W. (2002), Germanys Economic Unification. An Assessment After Ten Years, Review of International Economics, 10, 113-128.

Stiglitz, J. (2002), Globalization and its Discontents, New York, Norton.

Wagner, H. (1993), Reconstruction of the Financial System in East Germany: Description and Comparison with Eastern Europe, Journal of Banking and Finance, 17, 10011019.

Wagner, H. (1996), Transformation Process and the J-curve Problem, International Journal of Social Economics, 23(10/11), 73-87. 
Wagner, H. (2000), Which Exchange Rate Regimes in an Era of High Capital Mobility, North American Journal of Economics and Finance, 11, 191-203.

Wagner, H. (2001), Monetary Integration and Real Convergence, in The European Economic and Monetary Union, Regional and Global Challenges (Ed.) Caesar, R., Scharrer, H.-E., Bonn, Nomos, 79-95.

Wagner, H. (2002a), Pitfalls in the European Enlargement Process, Discussion Paper 06/ 02 (February 2002), Economic Research Centre of the Deutsche Bundesbank, Frankfurt/M.

Wagner, H. (2002b) Implications of Globalization for Monetary Policy, SUERF Studies No. 17, Vienna 2002, see also IMF Working Paper 01/184, November 2001, Washington, DC, International Monetary Fund.

Xie, X. (1999), Contagion through Interactive Production and Dynamic Effects of Trade, International Economic Review, 40, 165-86.

Young, A. (1991), Learning by Doing, and the Dynamic Effect of International Trade, Quarterly Journal of Economics, 106, 369-405.

Zhang, J. (2000), Public Services, Increasing Returns, and Equilibrium Dynamics, Journal of Economic Dynamics \& Control, 24, 227-46. 
Growth Effects of Heterogeneous Economic Integration: the Example of EMU Enlargement 645

\section{Appendix}

Table 1. GDP Convergence Indicator

\begin{tabular}{|c|c|c|c|c|}
\hline Candidate Countries & $\begin{array}{l}\text { Population } \\
\text { (millions) }\end{array}$ & $\begin{array}{c}\text { GDP per capita1) } \\
\text { (EUR) }\end{array}$ & $\begin{array}{c}\text { GDP per capita } \\
\text { (\% of euro area } \\
\text { average })^{1 / 2)} \\
1995\end{array}$ & $\begin{array}{c}\text { GDP per capita } \\
\text { (\% of euro area } \\
\text { average })^{1)} \\
2001\end{array}$ \\
\hline Bulgaria & 8.5 & 6,087 & 25 & 26 \\
\hline Cyprus & 0.6 & 20,028 & 83 & 88 \\
\hline Czech Republic & 10.3 & 14,016 & 62 & 60 \\
\hline Estonia & 1.4 & 9,406 & 30 & 40 \\
\hline Hungary & 10.0 & 12,208 & 45 & 53 \\
\hline Latvia & 2.4 & 7,021 & 24 & 30 \\
\hline Lithuania & 3.7 & 7,517 & 27 & 32 \\
\hline Malta & 0.4 & 13,372 & 49 & 58 \\
\hline Poland & 38.6 & 8,905 & 36 & 38 \\
\hline Romania & 22.4 & 6,050 & 32 & 26 \\
\hline Slovakia & 5.4 & 10,995 & 46 & 47 \\
\hline Slovenia & 2.0 & 16,240 & 64 & 70 \\
\hline $\mathrm{All}^{3)}$ & 105.6 & 9,126 & 38 & 39 \\
\hline Greece & 10.6 & 16,432 & 62 & 71 \\
\hline Portugal & 10.4 & 16,622 & 57 & 72 \\
\hline Spain & 40.0 & 19,964 & 70 & 86 \\
\hline Euro area ${ }^{3)}$ & 303.0 & 23,227 & 100 & 100 \\
\hline
\end{tabular}

Source: ECB, Monthly Bulletin, July 2002

(based on ECB, European Commission, World Bank and IMF World Economic Outlook)

1) In purchasing power parity (PPP) standards

2) For Greece, Portugal and Spain, the figure refers to the year of their EU accession, i.e. 1981 for Greece and 1986 for Portugal and Spain.

3) Weighted average, except for column 1 


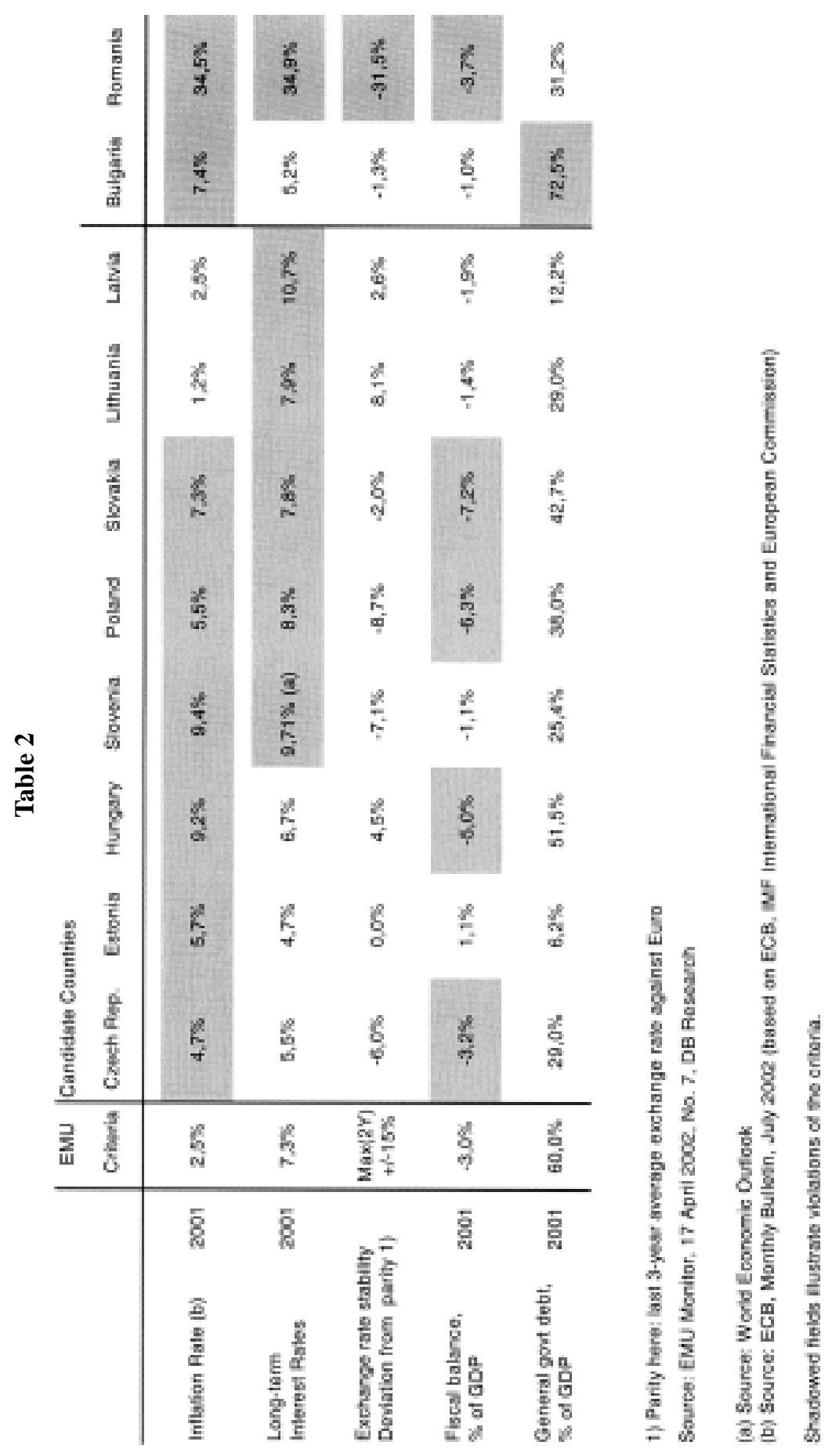


Growth Effects of Heterogeneous Economic Integration: the Example of EMU Enlargement 647

Table 3. Growth Effects of Heterogeneous Economic Integration The Example of EMU Enlargement 647

\begin{tabular}{|l|c|cccc|}
\hline & \multicolumn{5}{|c|}{ Political economy (2001) } \\
& $\begin{array}{c}\text { DB Research } \\
\text { convergence } \\
\text { indicator } \\
\mathbf{( 2 0 0 1 )}\end{array}$ & $\begin{array}{c}\text { Private } \\
\text { sector/GDP } \\
\text { in \% }\end{array}$ & $\begin{array}{c}\text { Legal } \\
\text { system } \\
\text { (EBRD) }\end{array}$ & $\begin{array}{c}\text { Banking } \\
\text { sector } \\
\text { (EBRD) }\end{array}$ & $\begin{array}{c}\text { Trade and fx } \\
\text { liberalisation } \\
\text { (EBRD) }\end{array}$ \\
\hline EU-15 & $\mathbf{1 0 0 , 0}$ & 80 & 10,0 & 10,0 & 10,0 \\
Czech Republic & $\mathbf{7 3 , 5}$ & 82 & 7,0 & 7,8 & 10,0 \\
Estonia & $\mathbf{7 1 , 4}$ & 75 & 8,5 & 7,8 & 10,0 \\
Hungary & $\mathbf{7 3 , 5}$ & 80 & 8,5 & 8,9 & 10,0 \\
Latvia & $\mathbf{6 6 , 2}$ & 65 & 7,8 & 6,6 & 10,0 \\
Lithuania & $\mathbf{6 4 , 6}$ & 72 & 8,1 & 7,0 & 9,3 \\
Poland & $\mathbf{6 2 , 1}$ & 73 & 7,7 & 8,1 & 10,0 \\
Slovakia & $\mathbf{6 1 , 0}$ & 84 & 7,4 & 6,6 & 10,0 \\
Slovenia & $\mathbf{7 4 , 7}$ & 65 & 8,5 & 7,0 & 10,0 \\
Bulgaria & $\mathbf{5 9 , 9}$ & 64 & 7,8 & 5,8 & 10,0 \\
Romania & $\mathbf{5 8 , 9}$ & 66 & 8,5 & 5,4 & 9,3 \\
\hline
\end{tabular}

Source: EMU Monitor, 17 April 2002, No. 7, DB Research 


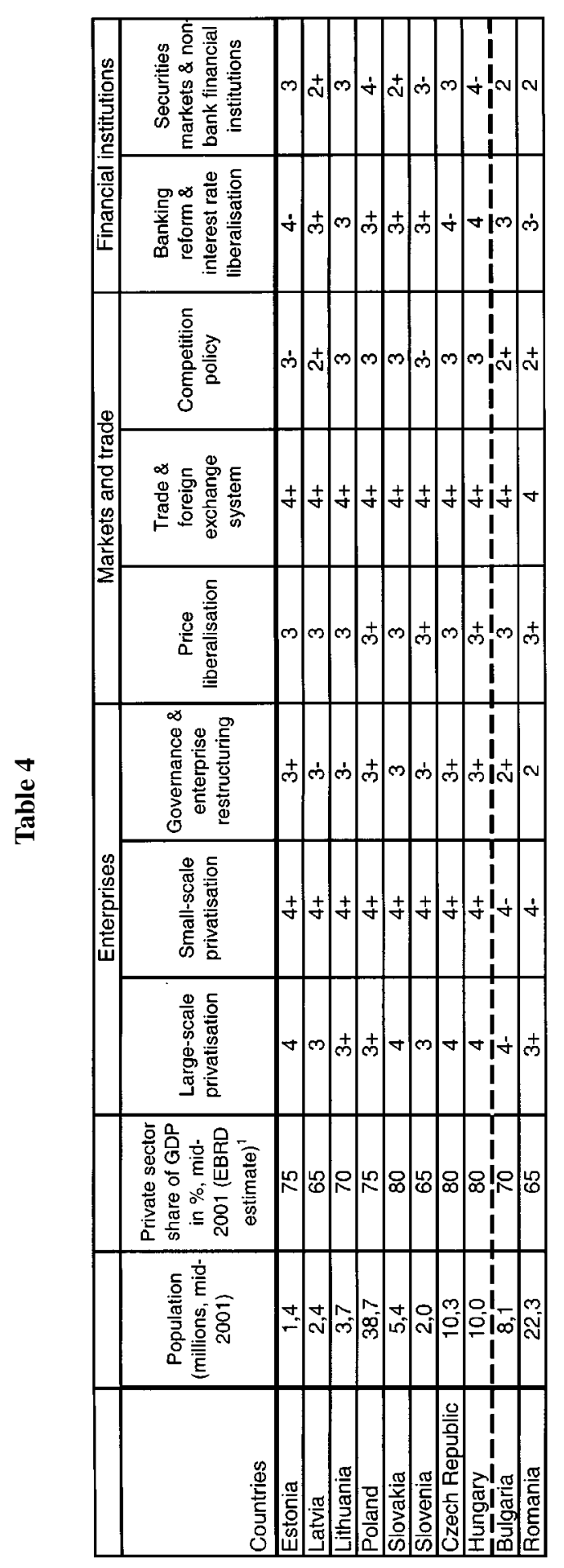

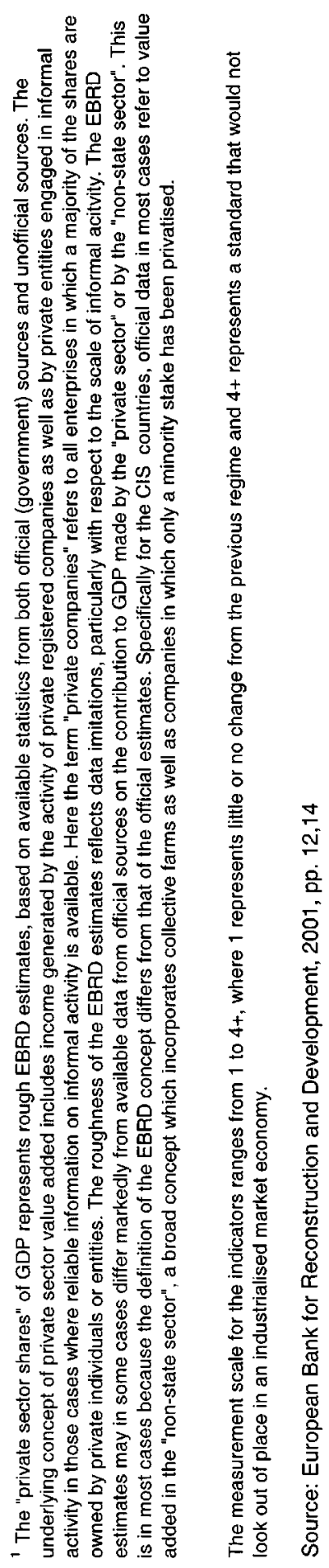


Growth Effects of Heterogeneous Economic Integration: the Example of EMU Enlargement 649

Table 5. Government Revenue and Expenditure

\begin{tabular}{l|cc} 
& $\begin{array}{c}\text { General } \\
\text { government } \\
\text { revenue } \\
(2000)\end{array}$ & $\begin{array}{c}\text { General } \\
\text { government } \\
\text { expenditure } \\
(2000)\end{array}$ \\
\hline (in per cent of GDP)(in per cent of GDP)
\end{tabular}

